\title{
An in-depth evaluation of personal barriers to technology adoption in irrigated agriculture in South Africa
}

Outlook on Agriculture

$1-10$

(C) The Author(s) 2021

Article reuse guidelines:

sagepub.com/journals-permissions DOI: I0.1 | 177/003072702098694 | journals.sagepub.com/home/oag

(S)AGE

\author{
Marlene de Witt' $₫$, Willem Petrus de Clercq', \\ Francisco José Blanco Velazquez ${ }^{2}$, Filiberto Altobeli ${ }^{3}{ }^{\circledR}$ \\ and Anna Dalla Marta ${ }^{4} \odot$
}

\begin{abstract}
Increasing pressure on water resources is driving the development of technology to improve water-use efficiency in irrigation. Uptake of these technological advances are essential to ensure long-term water security in catchments, particularly in water-scarce regions and where agricultural activities and urban centres compete for the same resources. Research suggests that uptake of technology lags far behind the development of new products. The study presented in this paper interviewed 29 commercial farmers from the water-scarce Central Breede River Valley in South Africa to investigate their reasons behind the use or non-use of irrigation technology for scheduling, and in particular the uptake of a free, government-funded remote-sensing service called FruitLook. Evaluating the uptake of a free service eliminates monetary cost as one key barrier to uptake. In-depth interviews revealed a high uptake of technology (83\%), but use of only one type - soil water measurement. Among the farmers that use water-use efficiency technology, 78\% use the same probe service provider. Perceived accuracy and ease of use, as well as personalised after-sales service are the key reasons for this probe's popularity. While $86 \%$ of the farmers have heard about FruitLook, only one farmer uses it for irrigation purposes. The non-use of the free service can mainly be attributed to the time cost associated with the product's initial set-up, use, and interpretation of information. The study revealed that the integration of information from various products is essential for farmers - too much information in different formats is too time-costly. Developers of new technology should focus on these latter two findings to improve the likelihood of new product uptake.
\end{abstract}

\section{Keywords}

Remote-sensing, information integration, innovation, water saving, irrigation technology

\section{Introduction}

Erratic and unpredictable climatic conditions, growing urban populations and resultant increased water demand, market conditions, pollution, and policy uncertainty are just a few factors that are putting pressure on the water resources available to farmers (Bijl et al., 2018; Flörke et al., 2018; Wei et al., 2011). Such pressures on farmers are no longer only confined to semi-arid to arid countries, as the 2018/2019 European season has shown (EEA, 2019). Growing urban water demand and climate change are predicted to cause substantial water deficits and increased resource competition (Flörke et al., 2018; Zhang et al., 2019). In most cases, agriculture is expected to free up water for redistribution to urban centres through improved efficiency (Flörke et al., 2018; Hamdy et al., 2003). This pressure has led to the development of numerous technological advances and decision-support systems aimed at enabling farmers to produce more with fewer inputs - Rose et al. (2016) for example found 395 such tools available to UK farmers alone.
A quick literature search suggests that studies investigating the actual uptake of these products and farmers' personal reasons for accepting or rejecting the products are much scarcer than the number of new products and models being developed. Uptake of new technology is generally

\footnotetext{
'Stellenbosch University Water Institute (SUWI), Stellenbosch University, Western Cape, South Africa

${ }^{2}$ Evenor-Tech "Technology-Based Company focus on Solutions for Soil Use and protection", Sevilla, Spain

${ }^{3}$ Research Centre for Agricultural Policies and Bio-economy - Council for Research in Agriculture and Agricultural Economy Analysis (CREA), Roma, Italy

${ }^{4}$ Department of Agrifood Production and Environmental Sciences, University of Florence, Firenze, Italy
}

\section{Corresponding author:}

Marlene de Witt, Stellenbosch University Water Institute (SUWI), Stellenbosch University, Al Perold Building, Victoria Street, Stellenbosch, Western Cape 7602, South Africa.

Email: marlenedw@sun.ac.za 
poor with a wide range of factors being possible deterrents, such as time or monetary cost, farmers' age, and farm size (Annandale et al., 2011; Garb and Friedlander, 2014; Parker, 2005; Parker and Campion, 1997). Farm size, financial position, and computer literacy are often found to be relevant factors in determining the probability of uptake among farmers (Annandale et al., 2011; Botha et al., 2000; Olum et al., 2019; Parvan, 2011; Pierpaoli et al., 2013; Reichardt and Jürgens, 2009; Rose et al., 2016; Stevens, 2006; Zhang et al., 2019). However, cost of technology is the most frequently mentioned barrier (Annandale et al., 2011; Garb and Friedlander, 2014; Parker, 2005; Parvan, 2011; Pierpaoli et al., 2013; Reichardt and Jürgens, 2009; Rose et al., 2016; Sadler et al., 2005; Stevens, 2006). Uptake is even poorer among small farmers in developing countries (Hamdy et al., 2003; Meijer et al., 2015; Ndjeunga and Bantilan, 2005; Olum et al., 2019).

The study presented in this paper used a relatively new, free remote-sensing tool, 'FruitLook' (www.fruitlook.co. za), available to farmers in the Western Cape in South Africa, as a case study to examine actual uptake of an innovative product where monetary cost is not a factor. FruitLook is a government-funded remote-sensing service developed in partnership between the Western Cape Provincial Government, Dutch satellite solutions company eLEAF, Hortgro and the Integrated Application Promotion Programme for the European Space Agency. It is an openaccess online platform, using satellite and weather information to monitor crop growth, crop water-use and leaf nitrogen content. FruitLook has been online since January 2012 and covers approximately 200000 hectares of crops.

This study evaluates farmers' reasons for their use or non-use of this free service, as well as of other decisionsupport technologies or products for irrigation scheduling in particular. Uptake or adoption is considered here to be regular use of a technology to aid decision-making.

The range of pressures facing South African farmers, together with their familiarity with irrigation and technology, makes it a good case study to test reasons for technology use or non-use among commercial farmers. The South African agricultural sector has suffered tremendously under recurring droughts over the past decade (Schreiner et al., 2018). In the Western Cape Province alone the 2015-2018 drought cost the economy R5.9 billion (EUR347 million). In a semi-arid country where irrigation uses $64 \%$ of all surface water, the climate is drying (CSIR, 2019) and pressure is placed on commercial farmers to reduce their consumption for re-allocation to towns and emerging farmers, it could be expected that South African commercial farmers would use the technology at their disposal to improve irrigation efficiency.

A long history of irrigation use in agriculture and the rising pressure on South African farmers to save water has led to local development of irrigation technologies and the adoption of international technologies and best practices (Annandale et al., 2011; Myburgh, 2018). However, in line with international findings, technology uptake remains poor. A survey of irrigation boards across South Africa found that only $18 \%$ of farmers use 'objective' methods (i.e. some form of technology) to inform their irrigation scheduling, with the rest relying on their experience and instinct (Stevens, 2006). Similarly, only a few crop models, developed for local markets, have been successfully adopted (Annandale et al., 2011). This shows that there is still much room for improvement in irrigation water-use efficiency, but that farmers' reluctance to adopt new technologies needs to be better understood if catchment-wide water-saving targets are to be achieved. Understanding commercial farmers' non-use of technology for irrigation is essential in order to begin to understand how to introduce this technology to smallholders (Krishna et al., 2020).

This study sought to determine the personal reasons behind farmers' adoption or non-adoption of technology to improve their irrigation water-use efficiency, and to discuss the outcomes in the context of international case studies and conceptual work on the topic. The work was conducted as part of the international OPERA ('Operationalising the increase of water-use efficiency and resilience in irrigation') project from the Water-JPI initiative of the European Union. The objective was addressed through two aims:

1) An assessment of farmers' current methods and technologies used for irrigation scheduling, and the reasons behind these choices of use or non-use of technology.

2) Evaluating the uptake of FruitLook and the reasons behind the use or non-use thereof.

The paper starts with an outline of the methodology used to address the objectives, which includes an overview of the chosen case study site. This is followed by the presentation and a discussion of the results in relation to international and local literature. The paper concludes with the most important findings and, based on these, recommendations for use by technology developers to improve uptake of their products.

\section{Methods}

Three methods were considered for information gathering on technology adoption: self-completion questionnaires, face-to-face interviews, and workshops. Many studies on technology uptake make use of self-completion questionnaires (e.g. Aubert et al., 2012; Montagu and Stirzaker, 2008; Stevens, 2006), but answers may be confined to a simple 'yes or no', or left blank (Harris and Brown, 2010). Workshops are often poorly attended and create the risk that not all attendees' opinions are adequately captured. Face-to-face interviews were chosen as an information gathering method as it allows the researcher to obtain detailed, insightful, personal reasons for the use or nonuse of technology (Glover et al., 2019). Interviews were conducted semi-structured in a conversational style, guided by a questionnaire, but adapting to each farmer's degree of openness. Interviews were conducted anonymously, in order to obtain honest answers. 


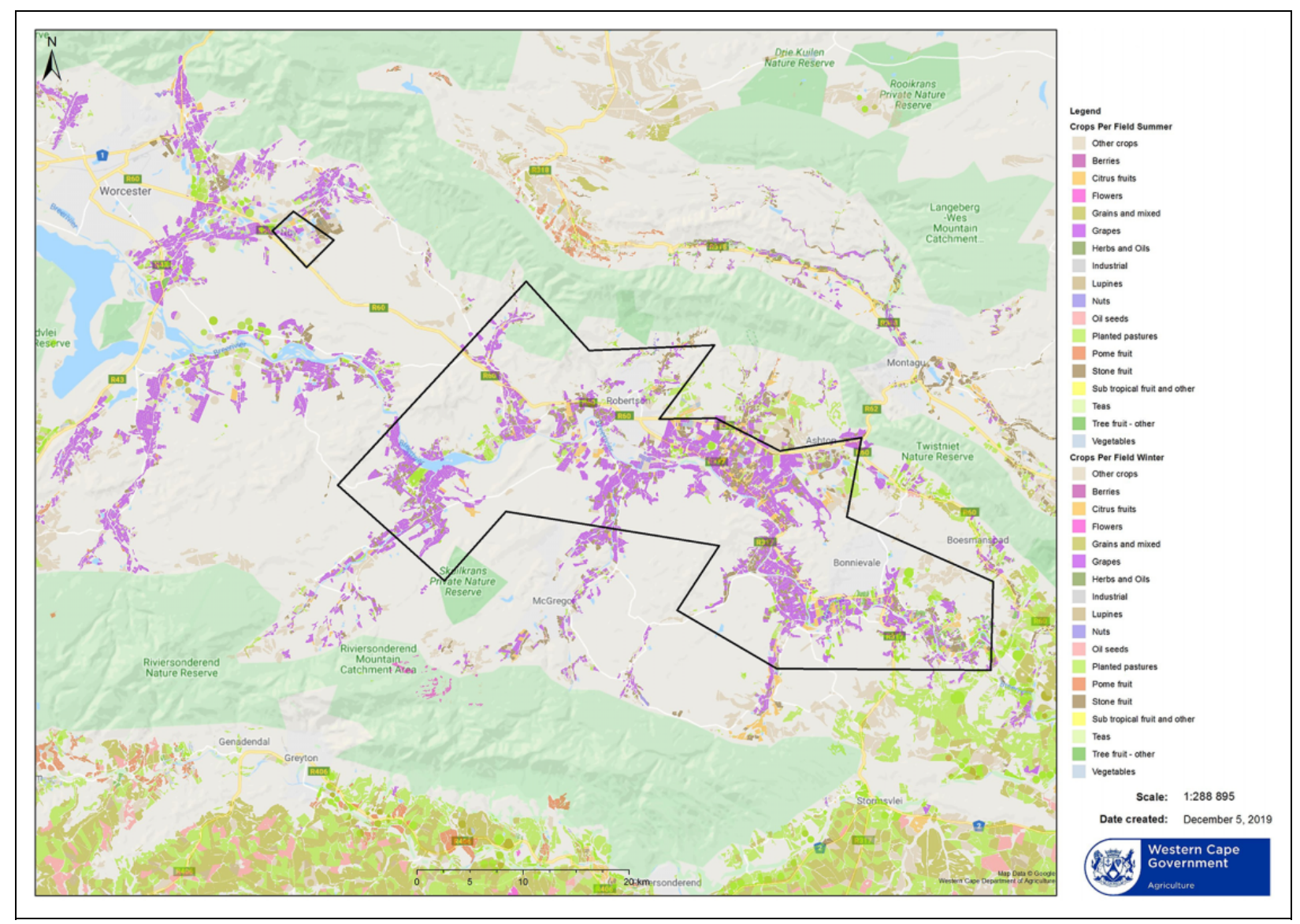

Figure I. All farms visited lie within the shaded area (map adapted from Cape Farm Mapper ${ }^{\circledR}$ ).

The chosen case study area was the Central Breede River in the greater Robertson area (see Figure 1), where much work has been done on irrigation technology and practices, which guarantees that many of the farmers in the area would have had exposure to technological developments. FruitLook was introduced in the area in 2014.

Answers were sought to the questions presented in Table 1. Answers to questions 2 and 3 (age and farm size) were compared with the answers of question 7 (use of technology for irrigation scheduling) to determine if there is a significant correlation between farmers' personal qualities and circumstances and technology uptake. This was done using an independent t-test between users and non-users of technology. The same was done for questions 2 and 3, and question 5 (how likely are you to use a new technology). The answers to questions 5 to 8 regarding technology interest and uptake were qualitatively analysed to identify similarities in farmers' answers and draw conclusions about the main reasons for uptake or non-uptake of technology. Questions 9 to 12, regarding FruitLook, were very open-ended as there were no predetermined information regarding farmers' use or non-use of this service. Answers were qualitatively analysed to determine the main reasons for the use or non-use of the service.

\section{Sample size}

While the total population size for the Central Breede River area can be obtained from Statistics South Africa, the exact
Table I. Questions used in the semi-structured interviews.

\begin{tabular}{|c|c|}
\hline $\begin{array}{l}\text { Profile of } \\
\quad \text { interviewees }\end{array}$ & $\begin{array}{l}\text { I. Name (only for researcher) } \\
\text { 2. Age } \\
\text { 3. Size of farm and area under cultivation } \\
\text { 4. Main crops planted (ha) }\end{array}$ \\
\hline $\begin{array}{l}\text { Technology interest } \\
\text { and uptake }\end{array}$ & $\begin{array}{l}\text { 5. On a scale of I-7, how likely are you to } \\
\text { experiment with a new technology when } \\
\text { you hear about it? Why? } \\
\text { 6. What type of irrigation do you use } \\
\text { (percentages)? } \\
\text { 7. How do you schedule your irrigation? } \\
\text { (What technology do you use?) } \\
\text { 8. Why do you use this technology in } \\
\text { particular? }\end{array}$ \\
\hline ook & $\begin{array}{l}\text { 9. Have you heard about FruitLook? } \\
\text { I0. Have you used it? If yes, how? If not, } \\
\text { why not? } \\
\text { II. What is your opinion about the } \\
\text { service? } \\
\text { 12. Should you sign up for a new tool, such } \\
\text { as FruitLook, how regularly would you } \\
\text { like to receive information } \\
\text { (continuously, daily, weekly etc.)? }\end{array}$ \\
\hline
\end{tabular}

number of active commercial farmers is not known. Also, many of the farmers own more than one farm. Traditional population sample size calculations could therefore not be used. Instead, the sample size target was set at $20 \%$ of cultivated land in the area. 


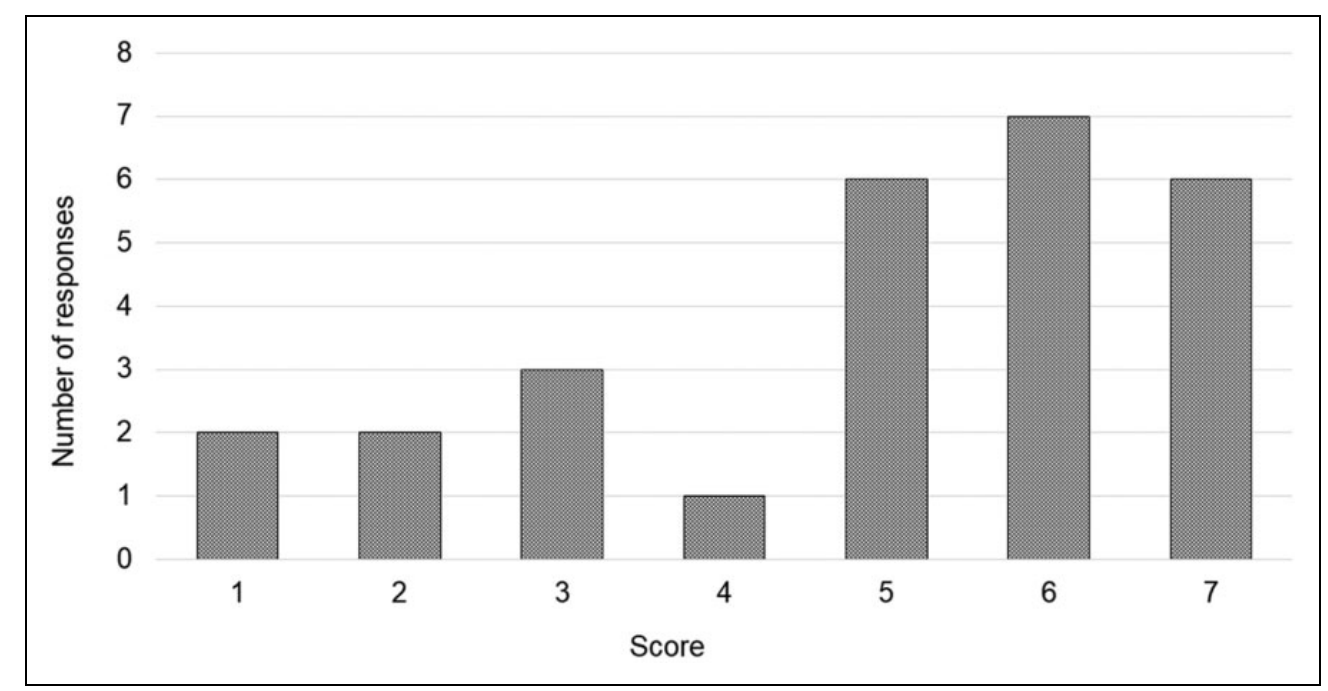

Figure 2. How likely are you to experiment with a new technology when you hear about it? $(I=$ unlikely, $7=$ highly likely $)$

A snowball (chain referral) sampling technique was used (Biernacki and Waldorf, 1981). It was assumed that farmers are more likely to respond positively to an interview request when they hear that their contact details were not obtained randomly, but from a person they know, and that this familiar person was also interviewed.

\section{Results}

Using the snowball sampling technique, interviewing started with two farmers known to the research team. From there, each farmer interviewed was asked for references. The contact list was developed until no new names were received. In this way, 36 farmers' names were obtained, with 29 persons agreeing to interviews. Interviews were conducted between May and August 2018.

\section{Profile of interviewees}

Farms visited ranged in size from 96 ha and 3500 ha, while cultivated area ranged from 34 ha to 700 ha (median $=$ 140 ha). Figure 1 shows the location of the farms visited. Combined, these 29 farmers have 4864 ha land under cultivation. This represents $21 \%$ of the total cultivated area in the wider Robertson region, which stood at 17 566 ha in 2017 (WCDA, 2018). In total, 74\% of crops planted by interviewees are vineyards, $7.5 \%$ citrus and lemons, with small amounts other fruit and vegetables. The ages of the persons interviewed ranged between 28 and 79 , with the median being 40 years. All interviewees were male.

\section{Technology interest and uptake}

Farmers were asked to rate, on a scale of 1 to 7 , how likely they are to experiment with a new technology after hearing about it. Figure 2 shows $74 \%$ of farmers scored between 4 and 7 , indicating that they are likely to experiment with new technologies (mean and median $=5$ ). Eight of the 19
Table 2. Statistically there is no relationship between age and technology adoption among the farmers interviewed.

AGE: Independent t-test

\begin{tabular}{lcccc} 
Mean: tech users & Mean: non-tech users & t-value & df & $\mathbf{P}$ \\
\hline 41.52 & 43 & -0.32 & 26 & ।
\end{tabular}

Table 3. There is no statistical relationship between farm size and the adoption of technology.

FARM SIZE: Independent t-test

Mean: tech users Mean: non-tech users t-value df $p$

\begin{tabular}{lllll}
\hline 180.89 & 138.4 & 0.66 & 26 & 0.14
\end{tabular}

farmers that chose high scores justified their answers by adding that they like to experiment with technologies 'only if it works'; they will 'first check what others do'; or 'it has to warrant the cost'.

There is a weak negative correlation $(\mathrm{r}=-0.44)$ between farmers' age and their likelihood of experimenting with new technology (question 5). There is no relationship $(\mathrm{r}=0.24)$ between farm size and farmers' likelihood of experimenting with new technology.

Farmers were asked to explain how they irrigate, how they determine their irrigation schedule, and what tools or methods they use to adapt the schedule (if any). All farmers apart from one (aged 79) used irrigation scheduling. All farmers said that experience and knowledge of one's farm, particularly of soils, are the most important factors in setting an irrigation schedule.

In total, 24 out of 29 farmers (83\%) use technology to inform their irrigation scheduling. There is no significant relationship between age and technology uptake $(p=1)$. The results are presented in Tables 2 and 3. There is no relationship between farm size (cultivated area) and technology uptake $(\mathrm{p}=0.14)$. 
Despite high levels of technology uptake (83\%), soil water measurement is the only type of technology used. The farmers' answers to question 7 (How do you schedule your irrigation; what technology do you use?) were detailed. The reported technologies and techniques were ranked according to their importance (1-3) to each farmer (Table 4). This was done by categorising the words used to describe each technology or technique. Farmers that did not talk openly were prompted with additional questions to ensure that all technologies used were mentioned. Results are presented in Figure 3.

Of the 24 farmers that reported using technology, 18 persons used continuous logging capacitance metre probes, 4 used Neutron metres, and 1 used a tensiometer (Figure 3). An additional three persons had formerly used continuous logging probes, but reverted to relying on experience instead. All farmers said they would not use technology to replace field measurements and experience. Checking

Table 4. Farmers' answers were analysed to distinguish between which technology or technique is the most important to them.

\begin{tabular}{|c|c|c|}
\hline $\begin{array}{l}\text { Words used to describe } \\
\text { use of technology or } \\
\text { technique }\end{array}$ & $\begin{array}{l}\text { Category } \\
\text { assigned }\end{array}$ & $\begin{array}{c}\text { Number } \\
\text { assigned } \\
\text { for analysis }\end{array}$ \\
\hline $\begin{array}{l}\text { Mentioned immediately; } \\
\text { 'adapt accordingly/based } \\
\text { on', 'daily', 'best', 'very } \\
\text { good', 'important' }\end{array}$ & $\begin{array}{l}\text { Most important, } \\
\text { check daily }\end{array}$ & I \\
\hline $\begin{array}{l}\text { Mentioned second; 'regularly', } \\
\text { 'weekly', 'often', 'use it', 'do } \\
\text { it', 'good', 'important' }\end{array}$ & $\begin{array}{l}\text { Important, check } \\
\text { regularly }\end{array}$ & 2 \\
\hline $\begin{array}{l}\text { 'At start of season only', } \\
\text { 'sometimes', 'only if there's } \\
\text { a problem' }\end{array}$ & $\begin{array}{l}\text { Use/do it, but not } \\
\text { regularly }\end{array}$ & 3 \\
\hline $\begin{array}{l}\text { 'No', 'don't use/do it', 'haven't } \\
\text { heard about it', 'used to } \\
\text { use/do it, but not anymore', } \\
\text { 'doesn't work' }\end{array}$ & Not at all & 0 \\
\hline
\end{tabular}

the plants' physiology was deemed the most important technique for farmers to make decisions regarding their scheduling $-48 \%$ of the farmers did this daily, and $28 \%$ did it weekly. Weekly soil profile checks were also widely used. One farmer's consultancy team used a pressure bomb on a weekly basis, and only one farmer used FruitLook to inform scheduling decisions (through a consultant).

Of the 18 persons that used continuous logging probes, 14 used a specific type (Irricon). The answers to question 9 (why do you use this particular technology?) are presented for the Irricon probes, to ascertain why this product in particular is so popular:

- Hourly readings are useful to make quick, in-field decisions.

- The probes are perceived to be accurate after they have been adjusted and calibrated over two to three seasons.

- The user interface is easy-to-use and navigate.

- Probes can be rented.

- The after-sales service is good. Farmers can phone the developers for advice and they deliver in-field support and servicing if and when needed.

Two additional points were raised. Firstly, many farmers specifically mentioned the importance of personal contact they prefer personal telephonic advice from an advisor they know and trust, rather than relying solely on a technological product. Second is the role that water distribution plays in farmers' will to adopt additional technologies to inform their irrigation decision-making. Farmers use the water as and when they receive it from the irrigation scheme, because if they do not have storage dams and do not use the water when they receive it, they will lose it.

\section{Fruitlook}

Only one farmer reported using FruitLook to inform irrigation scheduling (through a consultant). In total, $86 \%$ of

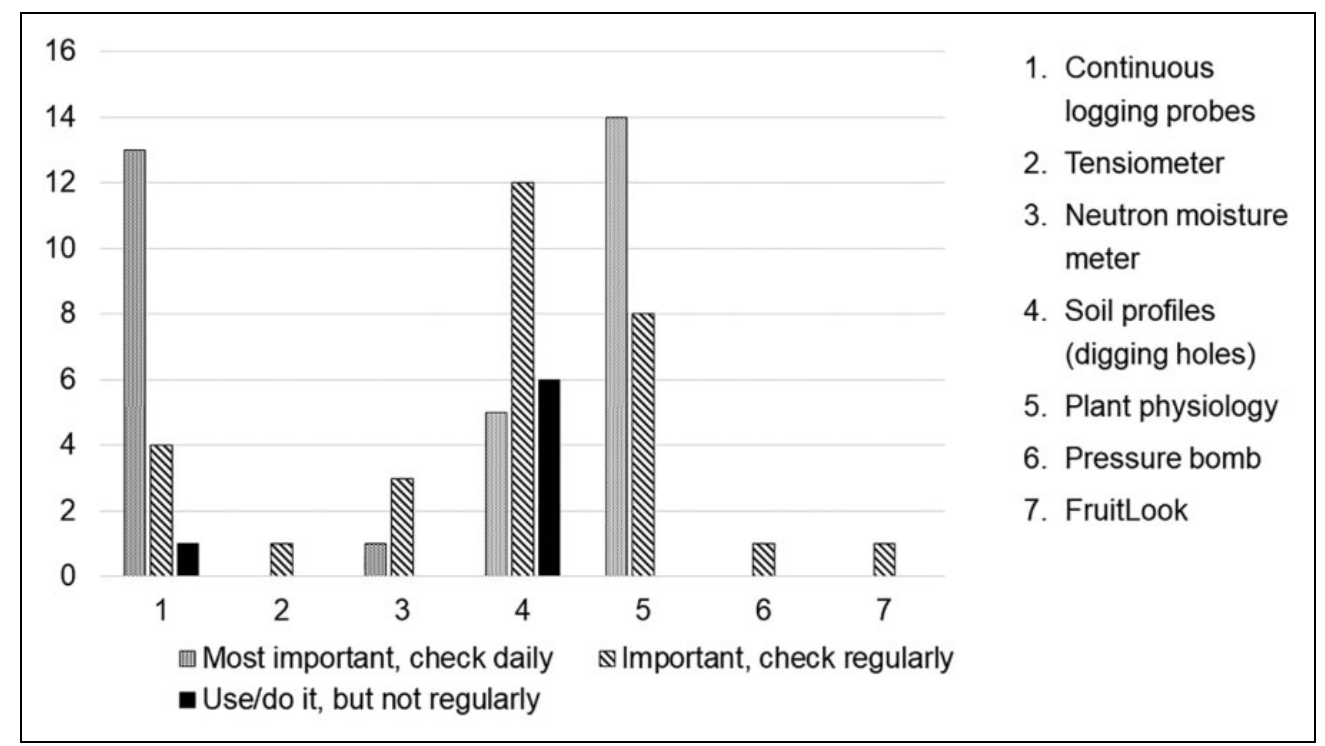

Figure 3. Decision-making tools that the farmers reported to use to inform their decision-making in irrigation scheduling. 
Table 5. Summary of perceived advantages and disadvantages of FruitLook.

\begin{tabular}{|c|c|c|c|}
\hline Advantages & \# people & Disadvantages & \# people \\
\hline Can help you to irrigate more accurately & 5 & $\begin{array}{l}\text { Still have to go into the field and check for } \\
\text { yourself, can't rely on it as management tool \& } \\
\text { won't replace probes }\end{array}$ & 13 \\
\hline Can identify problem spots & 8 & Time-intensive to set up & 8 \\
\hline Can help with prevention of problems & 2 & $\begin{array}{l}\text { Difficult to understand what all the data means } \\
\text { and how to apply it }\end{array}$ & 6 \\
\hline Have 5 years of history & 2 & Not accurate enough & 5 \\
\hline It's free & 2 & Get information a week later & 4 \\
\hline Can help bring production costs down & 1 & Picks up weed biomass, give false picture & 2 \\
\hline Can inform spraying programme & I & Only for technologically advanced & 2 \\
\hline Can help adapt farming holistically (not just water) & I & Can't update when cloudy & I \\
\hline Can help with fertiliser application & I & $\begin{array}{l}\text { One can't make small adjustments to entire } \\
\text { irrigation plan based on weekly picture }\end{array}$ & I \\
\hline $\begin{array}{l}\text { Learn how your crops work, understand farm and } \\
\text { plants better }\end{array}$ & I & Doesn't give solutions so doesn't add value & I \\
\hline $\begin{array}{l}\text { Comparison between different years help you } \\
\text { improve your strategy }\end{array}$ & I & & \\
\hline $\begin{array}{l}\text { Can increase marketing value for estates with } \\
\text { their own labels }\end{array}$ & I & & \\
\hline Problem-solving tool & I & & \\
\hline
\end{tabular}

interviewees (25 out of 29) stated that they have heard about FruitLook, had received training, or started experimenting with it. Only three farmers were actively using FruitLook, while one farmer had formerly used the programme, but stopped due to perceived inaccuracy. The farmers that have used FruitLook reported that the programme is useful to spot bad patches in the field, to inform the placement of their soil probes and check the functionality of the probes, and to understand their farms better.

Negative experiences with FruitLook include: the resolution, the fact that it's a weekly service (not regular enough to inform irrigation), its accuracy in terms of detecting weeds in biomass totals, and the effort required to understand the programme before one starts getting value out of the data received. The three farmers actively using FruitLook stated that they will never take decisions based on FruitLook; rather they use it as an additional problem-solving tool. Table 5 contains the perceived advantages and disadvantages of FruitLook, as expressed by the farmers who have used it, received training on, or experimented with it.

In addition to the formal questions, all interviewees were probed to think about whether they need extra products and information to improve their irrigation efficiency. Farmers generally agreed that information is important, but mentioned the following limitations of decision-support tools:

- Excessive technology use can lead to complacency or negligence; farmers prefer to actively observe rather than to 'farm from behind a computer' $(n=6)$.

- An excess of information does not aid decisionmaking $(n=4)$.

- Irrigation infrastructure constrains the farmer's ability to implement the information received from decision-support tools. Making minor daily changes is not possible and the cost of modifying entire irrigation system layouts is too great $(n=4)$.

- Good working knowledge of one's farm and soils limits the perceived usefulness of additional technol$\operatorname{ogy}(n=4)$.

Practically, farmers did not have the time to interpret data from multiple products with different types of information, offered on different platforms. The farmers trusted their probe information and did not see the need for receiving more information on top of this, as it will take time to apply that information in their daily decision-making. They did however indicate that they would use new technology if a consultant did the preparation and interpretation for them, or if it linked to the technology they currently use.

Farmers wanted information on an hourly (continuous) or at least daily basis. They were not satisfied that weekly remote-sensing data is useful, as it will be too late to rectify an identified problem. Out of 22 respondents, 6 would prefer their remote-sensing data in a continuous or hourly format, 9 persons preferred daily, 5 weekly and 2 less regularly than weekly.

\section{Discussion}

This study explored the reasons behind technology adoption for irrigation scheduling and the uptake of a free remote-sensing service in the Central Breede River Valley. The results show an increase in the uptake of technology for irrigation scheduling in comparison to earlier studies, with $83 \%$ of farmers using some form of technology for decision-making. This is much higher than current reports in the South African and international literature on scheduling technology uptake over the past decade, which was mostly around 18\% (Annandale et al., 2011; Montagu and Stirzaker, 2008; Stevens, 2006; Wang et al., 2015). 
It has been showed that droughts and water restrictions, as experienced here, are drivers for technology uptake (e.g. Levidow et al., 2014; Olum et al., 2019), yet interviewed farmers used only a single type of technology (soil water measurement). This suggests that most of the technologies on the market have barriers that prevent farmers from considering the additional information gain significant enough to make up for the additional effort required to obtain this information. Galioto et al. (2020) also found that having access to better information does not necessarily translate into changes in irrigation scheduling - extrinsic factors could hamper the internalisation and adoption of the information even though the information is of a good quality, as was the case here.

Of the farmers that use some form of soil water measurement, $75 \%$ of them use the same service provider (Irricon) for probes. Two main reasons for the success of this probe are in line with the reasons for successful technology uptake provided by Pierpaoli et al. (2013) in their literature review, namely perceived ease of use and perceived usefulness. Perceived accuracy, affordability (value for money), and particularly the probes' easy-to-use computer user interface that provides continuous management advice, were key drivers for uptake of the Irricon probes. A key finding was that after-sales service is of high importance a factor which is often overlooked by the developers of new technology (Annandale et al., 2011; Galioto et al., 2017; Garb and Friedlander, 2014; Parker, 2005). This was also reportedly the case in the widespread success of drip irrigation uptake in Israel (Garb and Friedlander, 2014).

The quality and accuracy of the products as judged by industry experts and academics are not equally important to farmers. Researchers are critical of soil water measurement instruments because of the impact of soil heterogeneity and other extrinsic factors that impact on the readings (e.g. Galioto et al., 2017; Myburgh, 2018). The Irricon probe modifies the soil water readings into an illustrative format on the user interface to serve as a practical management tool. This is a key factor that makes the product so popular. It is also one of the reasons that the farmers are not widely interested in FruitLook - FruitLook does not provide management recommendations and farmers do not have time for (or interest in) interpreting raw data. Farmers indicated that they are more likely to use FruitLook if the data can be interpreted for them in terms of a weekly summary, even more so if the data would be presented as complementary and linked to the data of their soil probes. The importance of management advice was also seen in cases in Europe (Levidow et al., 2014).

Despite being a free service, FruitLook is not widely used in the study area. It is considered to be too costly in terms of the initial time needed to set up one's fields, not accurate enough, and information not delivered timeously enough to inform irrigation decision-making. Cost-benefit and willingness-to-pay analyses usually only become relevant once monetary cost is involved in a product (Altobelli et al., 2018). This study showed how important it is to include time in cost-benefit analyses. If it costs too much time to operate and to obtain the necessary irrigation advice, it will not be adopted.

The poor uptake of FruitLook and limited use of technology for scheduling suggest that farmers seemingly do not have as great a desire for information as technology developers expect them to have. Indeed, 'farmers themselves decide whether to adopt the technology or not' (Krishna et al., 2020). The current development of farming apps that allow farmers to check various field measurements on their smartphones is indicative that technology developers are aiming to create tools to enable farmers to farm remotely, removing (partly or completely) the need for farmers to physically go into their fields. The farmers interviewed in this study are commercial farmers, exporting large quantities of their products, and many have the financial means to acquire additional technology. Yet, they still want to be outside in their fields; they do not want to farm remotely. 'I'm not going to sit inside the house and farm with a drone'; and 'There are many family farms here, technology won't easily replace the traditional way' are some of the points raised. Glover et al. (2019) argued that more attention should be given to farmers' perceptions in terms of their encounter with new technology, perceived affordances and responses to it. Here it was showed that the importance of farmers' perceptions about a technology - no matter how innovative the new technology may be - is not acknowledged enough in the development of new products.

Kuschke and Cassim (2019) identified insufficient support and lack of integration between technologies as barriers to the uptake of remote-sensing technology. The results of this survey emphasised how important it is for the developers of new technology to focus on integrating their products with those already in use by their target audience. Farmers believe that while information is important, too much information is not useful. They indicated that they would use FruitLook if the information could be linked to that of their soil probes.

Diverse responses on timing preference of a remotesensing service shows how difficult it is to create a product that will satisfy all farmers equally. There is a preference for hourly or daily information ( $68 \%$ combined), as opposed to $32 \%$ of persons that prefer weekly or less regular updates. Most farmers in this study felt that weekly updates (as received through FruitLook) are not sufficient and comes too late to implement changes in irrigation scheduling.

While most evidence in the literature indicates a link between technology adoption and farmers' age and farm size (Annandale et al., 2011; Botha et al., 2000; Olum et al., 2019; Parvan, 2011; Pierpaoli et al., 2013; Stevens, 2006), no significant relationship was found here. There is only a weak correlation between farmers' interest in new technology and age, which suggests that older farmers are slightly less interested in experimenting with new technology than younger farmers. It could be assumed that the rapid growth in smartphone and internet usage in South Africa over the past decade (Poushter et al., 2018) and, as such, improved computer skills, could have created confidence among 
older farmers to explore and use technological advances in their work.

Various externalities, such as the right enabling environment (circumstances, markets, policies, institutions etc.), are essential for successful technology uptake (Orr, 2018). Indeed, Orr (2018) showed that in many cases there is nothing about the technology itself that explains adoption or rejection thereof. An external driver in this case was the limitation of farm infrastructure, as also found by Botha et al. (2000). Many of the farmers will have to change their irrigation layouts if they want to be able to make more precise adaptations to their irrigation and this will be too expensive. Another external driver was the impact that the management of the irrigation scheme has on farmers' ability to adapt their scheduling for optimal irrigation. Farmers have set water allocations which they receive from the irrigation board at certain times. If they do not have storage dams, they have to irrigate as and when they receive water. This means over-irrigation could occur purely because they have to make use of the water they receive, or lose it. Adopting additional technology to become more water efficient will therefore not be of any use to them. While the certification requirements, price of water, and reliability of supply have been reported as factors that could impact on technology adoption (Altobelli et al., 2018, 2019; Annandale et al., 2011; Stevens, 2006), the impact of the management of an irrigation scheme is less widely reported, but in this case plays a significant role. Similarly in New Zealand farmers' irrigation decisions were found to be constrained by the reticulation of irrigation water (Srinivasan et al., 2017). It highlights an urgent need for decision-support tools to provide irrigation scheme managers with better information about actual water needs on farms at any given time, and for a close working relationship between farmers and irrigation scheme managers (Srinivasan et al., 2017).

\section{Conclusion}

Investigating the uptake of a new, free remote-sensing service among commercial farmers in a water-scarce region of South Africa provided useful insights for researchers and technology developers wishing to introduce innovations to support agricultural water-saving efforts. Using in-depth interviews as research method proved useful in gathering farmers' personal insights and opinions on new technology.

Five factors that play a key role in the successful adoption of a new technology emerged from this research:

- Too much information that comes in different software packages and needs to be interpreted separately is not practical, and farmers prefer to be out in their fields, rather than behind a computer. Even good quality, free-to-use products will not be adopted if they do not add significant value as a management tool and align with the farmers' existing information tools. Developers who wish to introduce a new technology need to look at ways in which it can be integrated with and complement existing technologies in a specific area.

- Farmers still place a high value on personal experience and intuition. Technology only aids decisionmaking and makes farmers aware of problems; farmers still act based on experience and intuition. Any new product will have to be of very high perceived value and usefulness in order to be adopted successfully.

- The personal interaction between the developer and their local client base plays a significant role in the successful uptake of a new product, and after-sales service is extremely important to farmers.

- Time cost plays a major role in uptake. FruitLook is considered too time-costly in terms of initial set-up and interpretation of results. This is in contrast to farmers' preferred soil water probe, which is considered a useful and easy-to-use management tool that supports decision-making.

- External factors also influence technology adoption. In this case, the management of the irrigation scheme and the availability of storage dams play a significant role in farmers' need for additional technology. Without storage dams, farmers have to use water as and when they receive it, which deems any additional technology to aid on-farm efficiency, useless to the farmer.

\section{Declaration of conflicting interests}

The author(s) declared no potential conflicts of interest with respect to the research, authorship, and/or publication of this article.

\section{Funding}

The authors would like to thank the EU and WRC (South Africa), the Ministry of Economic Affairs (The Netherlands), CDTI (Spain), MINECO (Spain), ANR (France), MIUR (Italy) and NCBR (Poland) for funding, in the frame of the collaborative international consortium OPERA financed under the ERA-NET Co-fund WaterWorks2015 Call. This ERA-NET is an integral part of the 2016 Joint Activities developed by the Water Challenges for a Changing World Joint Programme Initiative (Water JPI).

\section{ORCID iD}

Marlene de Witt (D) https://orcid.org/0000-0002-9911-490X Filiberto Altobelli (D) https://orcid.org/0000-0002-2499-8640 Anna Dalla Marta (D) https://orcid.org/0000-0002-4606-7521

\section{References}

Altobelli F, Lall U, Dalla Marta A, et al. (2018) Willingness of farmers to pay for satellite-based irrigation advisory services: a southern Italy experience. Journal of Agricultural Science 156(5): 723-730.

Altobelli F, Monteleone A, Cimino O, et al. (2019) Farmers' willingness to pay for an environmental certification scheme: promising evidence for water saving. Outlook on Agriculture 48(2): 136-142. 
Annandale JG, Stirzaker RJ, Singels A, et al. (2011) Irrigation scheduling research: South African experiences and future prospects. Water SA 37(5): 751-764.

Aubert BA, Schroeder A and Grimaudo J (2012) IT as enabler of sustainable farming: an empirical analysis of farmers' adoption decision of precision agriculture technology. Decision Support Systems 54(1): 510-520.

Biernacki P and Waldorf D (1981) Snowball sampling: problems and techniques of chain referral sampling. Sociological Methods \& Research 10(2): 141-163.

Bijl DL, Biemans H, Bogaart PW, et al. (2018) A global analysis of future water deficit based on different allocation mechanisms. Water Resources Research 54(8): 5803-5824.

Botha CAJ, Steyn GJ and Stevens JB (2000) Factors which influence the acceptability of irrigation scheduling with specific reference to scheduling models. WRC Report No 893/1/00: 221 Available at: http://www.wrc.org.za/wp-content/uploads/ mdocs/893-1-00.pdf (accessed 3 August 2020)

CSIR (2019) South Africa land and water use. Available at: https://www.csir.co.za/sites/default/files/Documents/10. \%20CSIR\%20CGA_A1_HIGHRES_South\%20Africa.pdf (accessed 11 January 2021).

EEA (2019) Climate Change Adaptation in the Agriculture Sector in Europe. Luxembourg: Publications Office of the European Union. Available at: https://www.eea.europa.eu/publications/ cc-adaptation-agriculture (accessed 3 August 2020)

Flörke M, Schneider C and McDonald RI (2018) Water competition between cities and agriculture driven by climate change and urban growth. Nature Sustainability 1(1): 51-58.

Galioto F, Raggi M and Viaggi D (2017) Assessing the potential economic viability of precision irrigation: a theoretical analysis and pilot empirical evaluation. Water (Switzerland) 9(12): 990.

Galioto F, Chatzinikolaou P, Raggi M, et al. (2020) The value of information for the management of water resources in agriculture: assessing the economic viability of new methods to schedule irrigation. Agricultural Water Management 227(October 2019): 105848.

Garb Y and Friedlander L (2014) From transfer to translation: using systemic understandings of technology to understand drip irrigation uptake. Agricultural Systems 128: 13-24.

Glover D, Sumberg J, Ton G, et al. (2019) Rethinking technological change in smallholder agriculture. Outlook on Agriculture 48(3): 169-180.

Hamdy A, Ragab R and Scarascia-Mugnozza E (2003) Coping with water scarcity: water saving and increasing water productivity. Irrigation and Drainage 52(1): 3-20.

Harris LR and Brown GTL (2010) Mixing interview and questionnaire methods: practical problems in aligning data. Practical Assessment, Research and Evaluation 15(1): 1.

Krishna VV, Yigezu YA, Karimov AA, et al. (2020) Assessing technological change in agri-food systems of the Global South: a review of adoption-impact studies in wheat. Outlook on Agriculture 49(2): 89-98.

Kuschke I and Cassim A (2019) Sustainable agriculture: market intelligence report. GreenCape, pp. 1-60. Available at: https:// www.green-cape.co.za/assets/Uploads/SUSTAINABLEAGRICULTURE-MIR-2019-WEB-01-04-2019.pdf (accessed 6 June 2020).
Levidow L, Zaccaria D, Maia R, et al. (2014) Improving waterefficient irrigation: prospects and difficulties of innovative practices. Agricultural Water Management 146: 84-94.

Meijer SS, Catacutan D, Ajayi OC, et al. (2015) The role of knowledge, attitudes and perceptions in the uptake of agricultural and agroforestry innovations among smallholder farmers in sub-Saharan Africa. International Journal of Agricultural Sustainability 13(1): 40-54.

Montagu KD and Stirzaker RJ (2008) Why do two-thirds of Australian irrigators use no objective irrigation scheduling methods. WIT Transactions on Ecology and the Environment 112: 95-103.

Myburgh PA (2018) Handbook for Irrigation of Wine Grapes in South Africa. 1st edn. Pretoria: Agricultural Research Council.

Ndjeunga J and Bantilan MSC (2005) Uptake of improved technologies in the semi-arid tropics of West Africa: Why is agricultural transformation lagging behind? e-Journal of Agricultural and Development Economics 2(1): 85-102.

Olum S, Gellynck X, Juvinal J, et al. (2019) Farmers' adoption of agricultural innovations: a systematic review on willingness to pay studies. Outlook on Agriculture 49(3): 187-203.

Orr A (2018) Markets, institutions and policies: a perspective on the adoption of agricultural innovations. Outlook on Agriculture 47(2): 81-86.

Parker CG and Campion S (1997) Improving the uptake of decision support systems in agriculture. In: Kure H, Thysen I and Kristensen AR (eds) First European Conference for Information Technology in Agriculture, Copenhagen, Denmark: The Royal Veterinary and Agricultural University, p. 501camp. ISBN 8774324659.

Parker GC (2005) Technology acceptance and the uptake of agricultural DSS. In: EFITA/WCCA Joint Congres on IT in Agriculture, 25-28 July 2005, Vila Real, Portugal, pp. 17-22.

Parvan A (2011) Agricultural technology adoption: issues for consideration when scaling up. The Cornell Policy Review 1(1): 5-31.

Pierpaoli E, Carli G, Pignatti E, et al. (2013) Drivers of precision agriculture technologies adoption: a literature review. Procedia Technology 8(Haicta): 61-69.

Poushter J, Bishop C and Chwe H (2018) Social media use continues to rise in developing countries but plateaus across developed ones. Available at: https://www.pewresearch.org/global/ 2018/06/19/social-media-use-continues-to-rise-in-develop ing-countries-but-plateaus-across-developed-ones/\#table (accessed 2 March 2020).

Reichardt M and Jürgens C (2009) Adoption and future perspective of precision farming in Germany: results of several surveys among different agricultural target groups. Precision Agriculture 10(1): 73-94.

Rose DC, Sutherland WJ, Parker C, et al. (2016) Decision support tools for agriculture: towards effective design and delivery. Agricultural Systems 149: 165-174.

Sadler EJ, Evans RG, Stone KC, et al. (2005) Opportunities for conservation with precision irrigation. Journal of Soil and Water Conservation 60(6): 371-379.

Schreiner BG, Mungatana ED and Baleta H (2018) Impacts of Drought Induced Water Shortages in South Africa: Sector Policy Briefs. Available at: http://www.wrc.org.za/wp-con tent/uploads/mdocs/2604 Vol2.pdf (accessed 4 July 2020) 
Srinivasan MS, Bewsell D, Jongmans C, et al. (2017) Just-in-case to justified irrigation: applying co-innovation principles to irrigation water management. Outlook on Agriculture 46(2): $138-145$.

Stevens JB (2006) Adoption of Irrigation Scheduling Methods in South Africa. Pretoria: University of Pretoria.

Wang J, Klein KK, Bjornlund H, et al. (2015) Adoption of improved irrigation scheduling methods in Alberta: an empirical analysis. Canadian Water Resources Journal 40(1): 47-61.
WCDA (2018) Mapping of agricultural commodities and infrastructure in the Western Cape 2017/2018. (accessed 6 June 2020)

Wei Y, Langford J, Willett IR, et al. (2011) Is irrigated agriculture in the Murray Darling Basin well prepared to deal with reductions in water availability? Global Environmental Change 21(3): 906-916.

Zhang B, Fu Z, Wang J, et al. (2019) Farmers' adoption of watersaving irrigation technology alleviates water scarcity in metropolis suburbs: a case study of Beijing, China. Agricultural Water Management 212(January 2018): 349-357. 